\title{
Erratum to: Elevated MTSS1 expression associated with metastasis and poor prognosis of residual hepatitis B-related hepatocellular carcinoma
}

\author{
Xiu-Yan Huang ${ }^{1 *+}$, Zi-Li Huang ${ }^{2+}$, Bin Xu ${ }^{3+}$, Zi Chen ${ }^{4}$, Thomas Joseph Re ${ }^{5}$, Qi Zheng ${ }^{1}$, Zhao-You Tang ${ }^{6}$
} and Xin-Yu Huang ${ }^{1 *}$

\section{Erratum}

Unfortunately, the original version of this article [1] did not include any funding information in the "Acknowledgements" section. The complete "Acknowledgements" section is included in full in this erratum.

\section{Acknowledgements}

The authors acknowledge the contribution of all investigators at all participating study sites. We thank Dr. Ju-Hong Yang, Metabolic Disease Hospital \& Tianjin Institute of Endocrinology, Tianjin Medical University (Tianjin, People's Republic of China), for expert technical assistance with statistical analysis. This study was supported by grants from the National Natural Science Foundation of China (No. 81272401), the International Foundation of Translational Medicine for Abroad Scholars and Students, U.S. and China (No.UCTMP2015-03C001), the Foundation of Shanghai Health Bureau, Shanghai, PR China (No. 2012QJ001A). Z.C. acknowledges the support from the Society in Science-Branco Weiss fellowship administered by ETH Zürich and National Institute of Health/National Cancer Institute (Grant number 1U01CA202123-01, Subaward number 113098-5093073).

\section{Author details}

'Department of General Surgery, Shanghai Jiaotong University Affiliated Sixth People's Hospital, 600 Yi Shan Road, Shanghai 200233, Peoples Republic of China. ${ }^{2}$ Department of Radiology, Xuhui Central Hospital, Shanghai 200031, Peoples Republic of China. ${ }^{3}$ Department of General Surgery, The Tenth People's Hospital of Tongji University, Shanghai 200072, Peoples Republic of China. ${ }^{4}$ Thayer School of Engineering, Dartmouth College, Hanover, NH 03755, USA. ${ }^{5}$ Department of Radiology, Boston Children's Hospital, Harvard Medical School, Boston, MA 02446, USA. ${ }^{6}$ Liver Cancer Institute and Zhongshan Hospital, Fudan University, Shanghai 200032, Peoples Republic of China.
Received: 8 June 2016 Accepted: 8 June 2016

Published online: 24 June 2016

\section{Reference}

1. Huang $X Y$, Huang $Z L$, Xu B, Chen Z, Re TJ, Zheng Q, Tang ZY, Huang XY. Elevated MTSS1 expression associated with metastasis and poor prognosis of residual hepatitis B-related hepatocellular carcinoma. J Exp Clin Cancer Res. 2016;35(1):85. doi:10.1186/s13046-016-0361-8.

\footnotetext{
*Correspondence: xyhuang1119@163.com; xinyuhuang9@163.com ${ }^{\dagger}$ Equal contributors

'Department of General Surgery, Shanghai Jiaotong University Affiliated Sixth People's Hospital, 600 Yi Shan Road, Shanghai 200233, Peoples Republic of
} China

(c) 2016 The Author(s). Open Access This article is distributed under the terms of the Creative Commons Attribution 4.0 International License (http://creativecommons.org/licenses/by/4.0/, which permits unrestricted use, distribution, and reproduction in any medium, provided you give appropriate credit to the original author(s) and the source, provide a link to the Creative Commons license, and indicate if changes were made. The Creative Commons Public Domain Dedication waiver (http://creativecommons.org/publicdomain/zero/1.0/) applies to the data made available in this article, unless otherwise stated.

Submit your next manuscript to BioMed Central and we will help you at every step:

- We accept pre-submission inquiries

- Our selector tool helps you to find the most relevant journal

- We provide round the clock customer support

- Convenient online submission

- Thorough peer review

- Inclusion in PubMed and all major indexing services

- Maximum visibility for your research

Submit your manuscript at www biomedcentral.com/submit 